\title{
ULTRASTRUCURAL STUDY OF BEE LOUSE VARROA DESTRUCTOR ANDERSON \&TRUEMAN 2000 (ACARI: VARROIDAE) WITH RESISTANCE MODELS FROM APIS MELLIFERA L
}

\author{
By \\ KHALAF NOUR ABD EL-WAHED AMMAR \\ Department of Zoology, Faculty of Science, South Valley University, Qena, Egypt \\ (drkhalafnour@yahoo.com)

\section{Abstract}

The ectoparasitic mite Varroa destructor is the most dangerous pest of honeybee Egyptian race Apis mellifera L., as it causes many losses in apiculture worldwide. Adult female mites are flattened with a dome-shaped dorsal shield. The present SEM study revealed that the flat ventral surface is composed of series of plates. There are 5 rows of small, chemoreceptor papillae posterior to the genito-ventro anal shield, and a unique respiratory structure (peritreme) is located laterally above Coxa III. Peritreme is a chitinized elongated area surrounding stigma opening, provided by a lid that looks like a rose with a curly thick inner membrane which has numerous teeth-like projections.

Mite' legs appeared to be modified for parasitism and each is tipped by one distal empodium. The pretarsus of the first pair of legs becomes a concave sucker and the pretarsus of the 3 pairs of the posterior legs consists of membranous amblacral pad (the caruncle). The mouthparts appeared well modified for its diet on bee hemolymph with its' powerful pedipalp for host attachment. High magnification revealed different types of setae distributed on the body, the mechano-receptor pedipalp short and long anal setae and dorsal shield sensory simple setae.

Key words: Apis mellifera, honeybee Egyptian race, pest-mites, Varroa destructor, SEM.

\section{Introduction}

Honey bees, Apis mellifera L. are considered the wings of agriculture due to their important role in crop pollination and hive products (honey, propolis, royal jelly, wax, bee venom, pollen, queens and bee packages). However, honey bees are reliable to be attacked by many insect pests, birds, mites and diseases inducing severe damages. $V$. destructor are the most serious pest of western honey bee colonies and one of the primary causes of honey bee decline (Dietemann et al, 2012).

The genus Varroa includes at least four species; $V$. jacobsoni, $V$. underwoodi, $V$. rindereri, and $V$. destructor. $V$. destructor was mistakenly lumped together with $V$. jacobsoni and most literature referring to $V$. jacobsoni prior to 2000 probably refers to the species now known as $V$. destructor (Anderson and Trueman, 2000; Rosenkranz et al, 2010). Both species parasitize the Asian honey bee, A. cerana.
Varroa mites can transmit multiple viruses to their hosts and these viruses, not the Varroa mites themselves, may cause the majority of the damage that bees experience while hosting the mites (Webster and Delaplane, 2001). The mites transmit several pathogenic microorganisms to A. mellifera as sacboord virus or SBV (Bailly, 1991) and acute paralysis virus or APV (Ball, 1985; Ball and Allen, 1988) by inoculating virus particles into the hemolymph of honey bees (Alippi et al, 1995). V. destructor is a vector for various honey bee viruses as Kashmir bee virus (KBV), sac brood virus, acute bee paralysis virus (ABPV), Israel acute paralysis virus (IAPV) and deformed wing virus (DWV). Daughenbaugh et al. (2015) attributed the high annual losses of honey bee colonies due to Infection with the Lake Sinai Viruses (LSVs). In Egypt, $V$. destructor, is the most destructive pest of $A$. mellifera as well as the disadvantages of using chemical pesticides in mite infested colonies (Thompson et al, 2003). 
The present study was carried out on scanning electron microscope to investigate the morphological characterization of Varroa destructor infesting local bees; Egyptian race Apis mellifera lamarkii as well as the resistance patterns of honeybee against Varroa mites.

\section{Materials and Methods}

Adult Varroa females were collected from Apis mellifera lamarkii in Sohag Governorate during autumn and winter of 2014 and were examined by SEM. Collected mites were stored in $70 \%$ ethyl alcohol, washed in $100 \%$ acetone followed by $100 \%$ ethyl alcohol, and mounted directly into Hoyer's mounting medium on glass slides. For SEM, the collected mites were washed in saline $0.9 \%$ fixed in $2.5 \%$ gluteraldhyde (pH.7.4) at $4^{\circ} \mathrm{C}$. Specimens were washed three times in phosphate buffer and post fixed in $1 \%$ osmium tetroxide in $0.1 \% \mathrm{M}$ phosphate buffer and dehydrated in graded series of ethanol. Specimens were then mounted on stubs with double adhesive tape and coated with gold using spimodulevac/sputter coater. The samples were examined with a high resolution scanning electron microscope (Jeol, 1200 Ex II) in Faculty of Science, South Valley University. Also, Varroa mites were collected by examining the debris of bees deposited on screen mesh placed on the floor of the hive. Large amounts of debris can be examined in the laboratory using flotation procedure.

\section{Results}

Bee colonies were found to be heavily infested; up to 6 mites per host were recorded. The mite inserts itself between the abdominal sclera in adult bees where it penetrates the intersegment membranes in order to ingest haemolymph. Sometimes it can also be found between the head and thorax.

General characters (Fig.1; Plates 1, 2 \&3): Adult female mites were flattened with a dome-shaped dorsal shield. The flat ventral surface was composed of series of plates. Varroa mites exhibit distinct sexual dimor- phism. The body of both sexes is divided into two distinct parts; idiosoma and gnathosoma. The female mites have flattened ellipsoidal idiosoma with greater width than length (measuring 1-1.8 $\mathrm{mm}$ long and 1.5$2 \mathrm{~mm}$ wide). They are reddish-brown to dark brown in color and oval in shape, the mite gnathosoma consists of mouthparts with two movable, sensory pedipalps (palpus) and two chelicerae, and has eight legs. The mite protrudes its gnathosoma vertically to the body axis. Each chelicera has two small teeth and moves like saw-blades. The entire surface of the body is covered with filaments and cluster of sensilla spines directed backwards and forwards in different size and shape.

The dorsal side is decorated with a network of reticulations and carries a large number of short simple setae; highly sclerotized; dorsoventrally flattened and a domeshaped dorsal shield. Tectum is absent. The opisthonotal margin of the dorsal side carries 22 pairs of thick hook-like spines. Ventrally, tritosternum is well developed and consists of a two long finely feathered lacinia sets on a trapezoidal base. The hypostome carries three pairs of seeming straight line and lacking the hypognathal denticles. The sternal shield is arch-like .The genito-ventral anal shield covered with network of reticulations, being narrow anteriorly, wide medially and pointed posteriorly. It bears large number of short simple setae, a pair of simple para-anal setae, and a single post-anal seta. The genital aperture is circular in shape and situated on the anterior part of the genito-ventral anal shield while the anal area is triangular in shape and has 2 thin serrated valves, and five rows of small, dentate papilla posterior to the genito-ventral anal shield.

Legs are tipped by one distal empodia. Legs I-IV have seven segments (including pretarsus), each of which carries a large number of long simple setae having different sizes. Legs II-IV fold in deep pits (foveolaepedales). Legs PI-PIV measure 0.4-0.6 $\mathrm{mm}$ in length. 
The stigma of the adult female mite is located laterally above Coxa III and is enclosed in a peritremated shield which has a slit at the end. A unique respiratory apparatus that appears typically tracheal, as those of the insect and other Arachnids. Peritreme is a chitinized elongated area surrounding stigma opening. The peritreme is provided by a lid that looks like a rose with a thick inner membrane which has numerous teethlike projections.

The pretarsus of the 3 pairs of the posterior legs (II-IV) consists of two main parts of a cuticular basal stalk and an extricable membranous amblacral pad (the caruncle), while the first pair of legs, the pretarsus becomes concave sucker. The caruncle when fully extruded and expanded becomes a bilobed sucker and when deflated the entire caruncle is retracted into the basal stalk. The basal stalk of the pretarsus with the sucker fully retracted into it resembles an inverted cone with its narrow portion attached to the apex of the tarsus.

High magnification revealed that all five segments of the pedipalp bear mechanic receptor setae with a basal socket; P-l carries one simple seta, P-2 carries a pair of simple setae, P-3 (palpal tibia) bears five simple setae, P-5 (palpal tarsus) carries nine pairs of simple setae, single solenodion and a thick palpal, a potele which has two unequal lines at the base of palpal tarsus.

Ultrastructural study reveals that the body surface has cavities which possibly help in directorial function and small spines that cover the dorsal surface. Small sessile papillae are found scattered in genito-ventral shield. Cutaneous sense organs or sensella are the most widely distributed on all parts of the body and appendages. All setae are named according to their position on the body (anal, postpalpal, palpal, posthypostomal, tarsus, coxae, and basis chelicerae). Setae are hollow cuticular process with comparatively thick walls; they are movable, articulated to the cuticle by a thin membranous ring around the base. On the outside of pedipalps, there is a pair of stilettos (S) or the knife used by the mite in the body of the bee.

The present study showed the existence of forms and patterns of varied resistance models against Varroa mites which are the result of honey bee hygienic behavior. These are as follows (Plate 3): Full dump in the ventral side, cracking in the legs, mouth parts, dorsal side, and crackdown in the dorsal side, distorted abdomens, missing and stubby biting legs.

\section{Discussion}

The parasitic mite (Acari: Mesostigmata: Varroidae) has been known as a major pest of honeybees around the world (Sammataro et al, 2000). Varroa mites attack honey bee colonies as an external parasite of adult and developing bees, by feeding on hemolymph, spreading disease, and reducing their lifespan. Varroa destructor (=jacobsoni) is one of the most serious pests of the honey bee, Apismellifera (Hymenoptera: Apidae), and its introduction into new countries is causing much concern to beekeepers throughout the world. Although the Varroa complex includes multiple species, $V$. destructor is the species responsible for the vast majority of the damage attributed to mites from this genus. Until 2000, it was believed that $V$. jacobsoni Oudemans 1904 was the mite responsible for widespread honey bee colony losses. However, taxonomic work published in 2000 (Anderson and Trueman 2000) indicated that a previously-unidentified species of Varroa $(V . d e-$ structor) was responsible for the damage, while $V$. jacobsoni was shown to be only moderately harmful to western honey bees.

Anatomically, female Varroa mites are welladapted bee parasites. Their curved, flattened shapes allow them to fit between the abdominal segments and are held there by the shape and arrangement of ventral setae. This protects them from the bee's normal cleaning habits. Furthermore, they have claws that allow them to grasp the bee and ventral setae that allow them to remain at- 
tached to the bee. Additionally, the cuticle is highly-sclerotized, thus occasionally protecting it from bee aggression. Females use teeth on third movable digits and stilettos to open a wound on the host. The females attach to the adult bee between the abdominal segments or between body regions (headthorax-abdomen), making them difficult to detect. These are also places from which they can easily feed on the bees' hemolymph. The adult bee suffers not only the loss of blood but may be subjected to microbial invasion, leading to a reduced life expectancy.

The flattened shape of the female's body makes it easy for the mite to hold on to a bee and move easily into the cells of developing bee brood. When on adult bees, female Varroa are found mainly on the top of the bee's thorax at the point where the wings attach, between the head and the thorax, between the thorax and the abdomen, or between overlapping segments of the abdomen. These are places where the mites can easily use their piercing mouthparts to penetrate the exoskeleton of their host and gain access to the bee's hemolymph. These are also places where mites are less likely to be removed by the bee's grooming.

Bautz and Coggins (1992) showed that the legs were tipped by one of 2 types of distal empodia. Liu and Peng (1990) found that the pretarsus consists of a bilobed sucker. While Ramirez and Malavasi (1991) suggested that the ambulacrum is not a sucker or a sticky pad but a structure with protractile claw-like sclerites as crochets to grasp the hairs of the bee and allow the mites to move rapidly on the adult bees and other substrata. The present study showed that the first leg bears a concave sucker and the posterior three legs carry the caruncle.

Liu (1982) observed the dorsal shield is covered with numerous branched setae, and has a row of thick, short and curved setae at its lateral edges. While in the present work the dorsal shield is covered with pilose not branched setae, and has 22 pairs of thick, strong curved setae at its lateral edges. Moreover there are 5 rows of small may be chemoreceptor papillae posterior to the anus. Two blunt-tipped sensilla arising from the distal end of the tibia and five stout setae on the tarsus are observed.

The morphology of the living mite, its mouth parts and the mechanism of ingestion were examined by SEM. For penetration of the host integument, the mite protrudes its gnathosoma vertical to the body axis and with the two chelicerae, each with two small teeth and moving like saw-blades, a pair of stilettos or the knife, the mite tears a wound in the bee's integument. The out flowing blood is then sucked up by the muscular pharynx in the hypostoma. The same finding was recorded by Gelbe et al. (1987). All 5 segments of the pedipalp bear mechanoreceptor setae with a basal socket. The same finding recorded by Milani \& Ritter (1991); But in the present study; the number and sizes are differing from them.

By SEM, Puerta et al. (1990) found spores of Ascosphaera apis and Spiltoir and Aspergillus flavus, on the cuticle of adult female Varroa. The mite is also one of the vectors of Hafnia alue, which causes septicemia (Strick and Madel, 1988) and of several other bacteria (Glinski and Jarosz, 1992). Alippi (1992) showed that $V$. jacobsoni carries viable spores of Paenibacillus larvae. In the present spores and viruses are present as clusters in the dorsal surface.

Evidence suggested that Varroa and their vectored viruses affect the immune response of honey bees, making them more susceptible to disease agents (Yang and Cox-Foster 2005). The effects of the parasite on honey bees range from weakening to death of parasitized colonies, with the intensity of the problem related to the infestation level (De Jong, 1990).

Among the different types of A. mellifera, Africanized bees show great resistance to Varroa compared to bees of European races. One of the factors that is thought to be involved in this resistance is the fact that the 
reproductive ability of Varroa females is known to be lower in Africanized bees than in European bees (Camazine, 1986; Moretto, 1988).

Ruttner and Hanel (1992) mentioned that by investigating freshly killed mites it was concluded that the damage was caused by the mandibles of worker bees; SEM of the mandibles indicate that they act like sharp scissors. Peng et al. (1987) observed that $A$. cerana has a strong defense mechanism against Varroa jacobsoni. Defense mechanisms against the mite are similar to those of A.cerana in Africanized bees where mutilations in several parts of their body were noticed indicating possible attacks by the workers (Moretto et al.1993).

Honey bee colonies that survive infestations of this Varroa haplotype have one or more behavioral or physiological traits. Honey bees clean themselves (autogrooming) and nestmates (allogrooming) (Haydak, 1945). Grooming may injure or kill Varroa mites (Ruttner and Hanel, 1992), or it may cause mites to either move to other parts of the autogroomer's body, transfer to a new host or be removed from the bee's body without causing visible injury (Büchler et al, 1992). Variation among honey bee stocks in grooming has been inferred from the proportion of mites that drop to hive floors that are damaged, apparently from bees' mandibles (Boecking and Spivak, 1999; Fries et al, 1996; Rinderer et al, 2001; ArechavaletaVelasco and Guzman-Novoa, 2001). Alternately, they may be healthy, fallen owing to hot weather (Webster et al, 2000). Injuries to mites may result from grooming, removal of dead mites (Rosenkranz et al, 1997; Bienefeld et al, 1999), or predation by wax moth larvae and ants (Szabo and Walker, 1995). These results are consistent with what is recorded in the present work.

There are two genetic lines that breeders have been working on in the U.S. One line is called the leg-biters as its name would suggest, these bees are prone to attack Varroa, typically biting off the legs of the mites. The other genetic line is called Varroa-sensitive hygiene (VSH). In these bees, the workers can detect developing larvae and pupae that are infested with Varroa, and then the workers remove these larvae and pupae before the Varroa mites can complete their life cycle on them (Harbo and Harris, 2005; Harris, 2008). It is important to determine if honey bees have any heritable defense mechanisms against the mite which may be readily incorporated into breeding programs. Breeding for Varroa-resistant honey bees became the primary goal for a number of research groups around the world.

Generally speaking, honey has been used orally and topically to treat various ailments including gastric disturbances, ulcers, skin wounds, and skin burns by ancient Greeks, Egyptians and in Ayurveda and traditional Chinese medicine (Pećanac et al, 2013).

\section{Conclusion}

Religious significance; the use of honey as a great medicinal and health food has been documented in Hinduism, the Hebrew Bible, in the Christian New Testament, and in the Holly Qur'an. Also, the healing qualities of honey were referred to by philosophers and scientists all the way back to ancient times, such as Aristotle (384-322 BC) and Aristoxenus (320 BC).

No doubt, the protection of bees against its aggressive pest mite Varroa destructor is a must not only in Egypt but also worldwide for human welfare.

\section{Acknowledgement}

The author would like to thank Prof. Dr. Manal F. El-Garhy, Department of Zoology, Faculty of Science, Cairo University, for kindly revising the manuscript.

\section{References}

Alippi, AM, 1992: Transporte de esporas de Bacillus larvae por el acaro Varroa jacopsoni. Rev. Facult. De Argonomi, de La Plata 68:83-6.

Alippi, AM, Albo, GN, Marcangeli, J, Leniz, D, Noriega, A, 1995: The mite Varroa jacobsconi does not transmit American foul brood from infected to healthy colonies. Exp. Appl. Acarol. 19, 10:607-13. 
Allen, M, Ball, BV, 1996: The incidence and world distribution of the honey bee viruses. Bee World 77:141-62.

Anderson, DL, Trueman, JWH, 2000: Varroa jacobsoni (Acari: Varroidae) is more than one species. Exp. Appl. Acarol. 24, 3:165-89.

Arechavaleta-Velasco, M, Guzman-Novoa, E, 2001: Relative effect of four characteristics that restrain the population growth of the mite Varroa destructor in honey bee (Apis mellifera) colonies, Apidol. 32:157-74.

Baily, 1, 1991: Honey bee pathology, $2^{\text {nd }}$ edition; Academic Press; London, New York.

Ball, BV, 1985: Acute paralysis virus isolated from honey bee colonies infested with Varroa jacobsoni. J. Apic. Res. 24:115-9.

Ball, BV, Allen, MF, 1988: The prevalence of pathogens in honey bee (Apis mellifera) colonies infested with the parasitic mite Varroa jacobsoni, Ann.Appl.Biol.113:224-37.

Bautz, RA, Coggins, JR, 1992: Scanning electron microscopy of female Varroa jacobsconi (Acarina), ectoparasite of the honeybee Apis mellifera. Trans. Amer. Microsc. Soc. 111, 1: 28-34.

Bienefeld, K, Zautke, F, Pronin, D, Mazeed, A, 1999: Recording the proportion of damaged Varroa jacobsoni Oud. in the debris of honey bee colonies (Apis mellifera), Apidol. 30:24956.

Boecking, O, Spivak, M, 1999: Behavioral defenses of honey bees against Varroa jacobsoni Oud. Apidol. 30:141-58.

Büchler, R, Drescher, W, Tornier, I, 1992: Grooming behavior of Apis cerana, Apis mellifera and Apis dorsata and its effects on the parasitic mites. Bull. Insectol.56, 1:175-81.

Camazine, S. 1986: Differential reproduction of the mite Varroa jacobsoni, on Africanized and European honeybees. Ann. Entomol. Soc. Am. 79: 801-3.

Daughenbaugh, KF, Martin, M, Brutscher, LM, Cavigli, I, Garcia, E, et al, 2015: Honey Bee Infecting Lake Sinai Viruses. Viruses 7, 6: 3285-309

De Jong, D, 1990: Mites: Varroa and other parasites of brood. In: Honey Bee Pests, Predators and Diseases (Morse, RA, and Nowogrodski, R, eds). Cornell University Press, Ithaca.

Dietemann, V, Pflugfelder, JD, Anderson, DJ, Charrière, N, Chejanovsky, B, et al, 2012: Varroa destructor research avenues towards sustainable control. J. Apic. Res.51, 1:125-32.
Evans, GO, 1992: Principles of Acarology. CAB: International, Wallingford, UK.

Fries, I, Huazen, W, Wei, S, Jin, CS, 1996: Grooming behavior and damaged mites (Varroa Jacobsoni) in Apis cerana cerana and Apis mellifera ligustica, Apidol. 27:3-11.

Gelbe, R, Kurscheid, D, Madel, G, 1987: The ectoparasitic bee-mite Varroa jacobsconi: Investigations on the morphology of mouthparts and histology of salivary glands. Zentralplatt. Bakteriol. Mikrobiol. Hyg. 265:489-98.

Glinski, ZF, Jarosz, J, 1992:Varroa jacobsoni as a carrier of bacterial infections to recipient bee host. Apidol. 23:25-31.

Harbo JR, Harris, JW, 2005: Suppressed mite reproduction explained by the behavior of adult bees, J. Apic. Res. 44:21-3.

Harris, JW, 2008: Effect of brood type on Varroa sensitive hygiene by worker honey bees (Hymenoptera: Apidae), Ann. Entomol. Soc. Am. 101, 11:37-44.

Haydak, MH, 1945: The language of the honey bees, Am. Bee J. 85:316-7.

Liu, TP, 1982: A scanning electron microscope study on the female mite Varroa jacobsconi (Oudemans, 1904). Am. Bee J. 122, 6:413-5.

Liu, TP, Peng, YSC, 1990: Scanning electron microscopic observation of the pretarsal suckers of the honey-bee ectoparasite, Varroa jacobsoni (Gamasida: Dermanyssina). Exp. Appl. Acarol. 8:114-95

Milani, N, Ritter, W, 1991: Sense receptors of the palp of Varroa jacobsoni oud. (Varroidae, Meso-stigmata): SEM observations. Proceed. Int. Symp. Recent Research Bee Pathology. September 5-7, 1990, Ghent, Belgium.

Moretto, G, Gonçalves, LS, De Jong, D, 1993: Heritability of Africanized and European honeybee defensive behavior against the mite Varroa jacobsoni. Rev. Bras. Genét. 16:71-7.

Oudemans. AC, 1904: On a new genus and species of parasitic Acari: Notes from the Leyden Museum.

Peng, YS, Fang, Y, Xu, S, Ge, L, 1987: The resistance mechanism of the Asian honeybee Apis cerana Fabr. to an ectoparasitic mite Varroa jacobsoni Oudemans. J. Invert. Pathol. 19: 54-60.

Pećanac, M, Janjić, Z, Komarcević, A, Pajić, M, Dobanovacki, D, et al, 2013: Burns treatment in ancient times. Med. Pregl. 66, 5/6: 2637 
Puerta, F, Flores, JM, Jimenez, AJ, Busters, M, Padilla, F, 1990: Enfermed adessecundarias a la parasitacion por Varroa en Apis mellifera. Vida Apicol. 43:54-9.

Ramirez, WB, Malavasi, GJ, 1991: Conformation of the ambulacram of Varroa jacobsconi Oud. (Mesotigmata: Varroidae): A grasping structure. Int. J. Acarol. 17, 3:169-73.

Rinderer, TE, de Guzman, LI, Delatte GT, Stelzer JA, Lancaster, VA, et al, 2001: Resistance to the parasitic mite Varroa destructor in honey bees from far-eastern Russia. Apidol. 32:381-94.

Rosenkranz, P, Aumeier, P, Ziegelmann, B, 2010: Biology and control of Varroa destructor. J. Invert. Pathol. 103:96-119.

Rosenkranz, P, Fries, I, Boecking, O, Sturner, M, 1997: Damaged Varroa mites in the debris of honey bee (Apis mellifera L.) colonies with and without hatching brood. Apidol. 28: 427-37. Ruttner, F, Hänel, H, 1992: Active defense against Varroa mites in a Carniolan strain of honeybee (Apis mellifera carnica Pollman). Apidol. 23:173-87.

Sammataro, D, Gerson, U, Needham, G, 2000: Parasitic mites of honey bees: life history, implications and impact. Ann. Rev. Entomol. 45:519-48.

Strick, H, Madel, G, 1988: Transmission of the pathogenic bacterium Hafniaalvei to honey bee by the ectoparasitic mite Varroa jacobsoni. In: Africanized Honey Bees and Bee Mites. By Nedham, JG, Ellis Harwood, Cheshire.

Szabo, TI, Walker, CRT, 1995: Damages to dead Varroa jacobsoni caused by the larvae of Galleria mellonella, Am. Bee J. 135, 421-2.

Thompson, H, Richard, B, Rown, MB, Medwin, BEW, 2003: Varroa destructor resistance to pyrethroid treatments in the United Kingdom. Bull. Insectol. 56, 1:175-81.

Webster TC, Thacker EM, Vorisek, FE, 2000: Live Varroa jacobsoni (Mesostigmata: Varroidae) fallen from honey bee (Hymenoptera: Apidae) colonies, J. Econ. Entomol. 93, 1: 596-601.

Webster, TC, Delaplane, KS, 2001: Mites of the Honey Bee. Dadant \& Sons, Inc. Hamilton, Illinois, USA.

Yang, X, Cox-Foster, DL, 2005: Impact of an ectoparasite on the immunity and pathology of an invertebrate: Evidence for host immunosuppression and viral amplification. Proceed. Natl. Acad. Sci. USA 102, 21:7470-5.

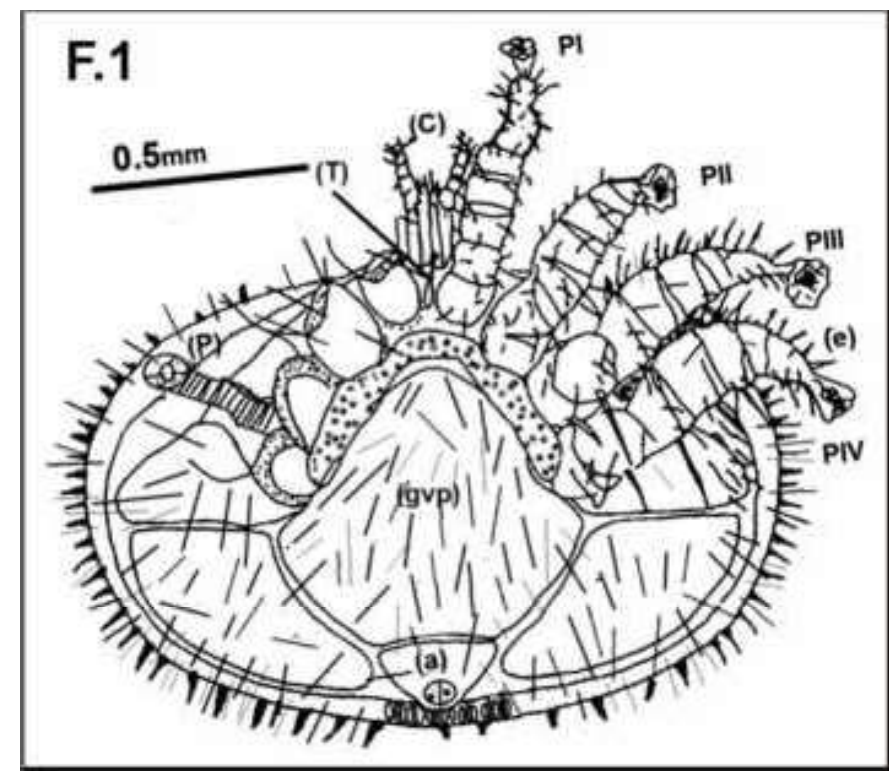

Fig.1: Camera Lucida drawing whole mount adult Varroa destructor female: Note: flat ventral surface composed of a series of plates. Body divided into two distinct parts; idiosoma and gnathosoma, mouthparts with two movable, sensory pedipalps (palpus) and two chelicerae (C), and eight legs (PI-PIV). Genital aperture circular in shape on anterior part of genito-ventro plate (gvp); anal area (a) triangular in shape with 2 thin serrated valves \& five rows of small, spine papilla posterior to anal shield (e) empodium, (t) tritosternum, (P) peritrem, Margin dorsally with 22 pairs of thick hook-like spine. 

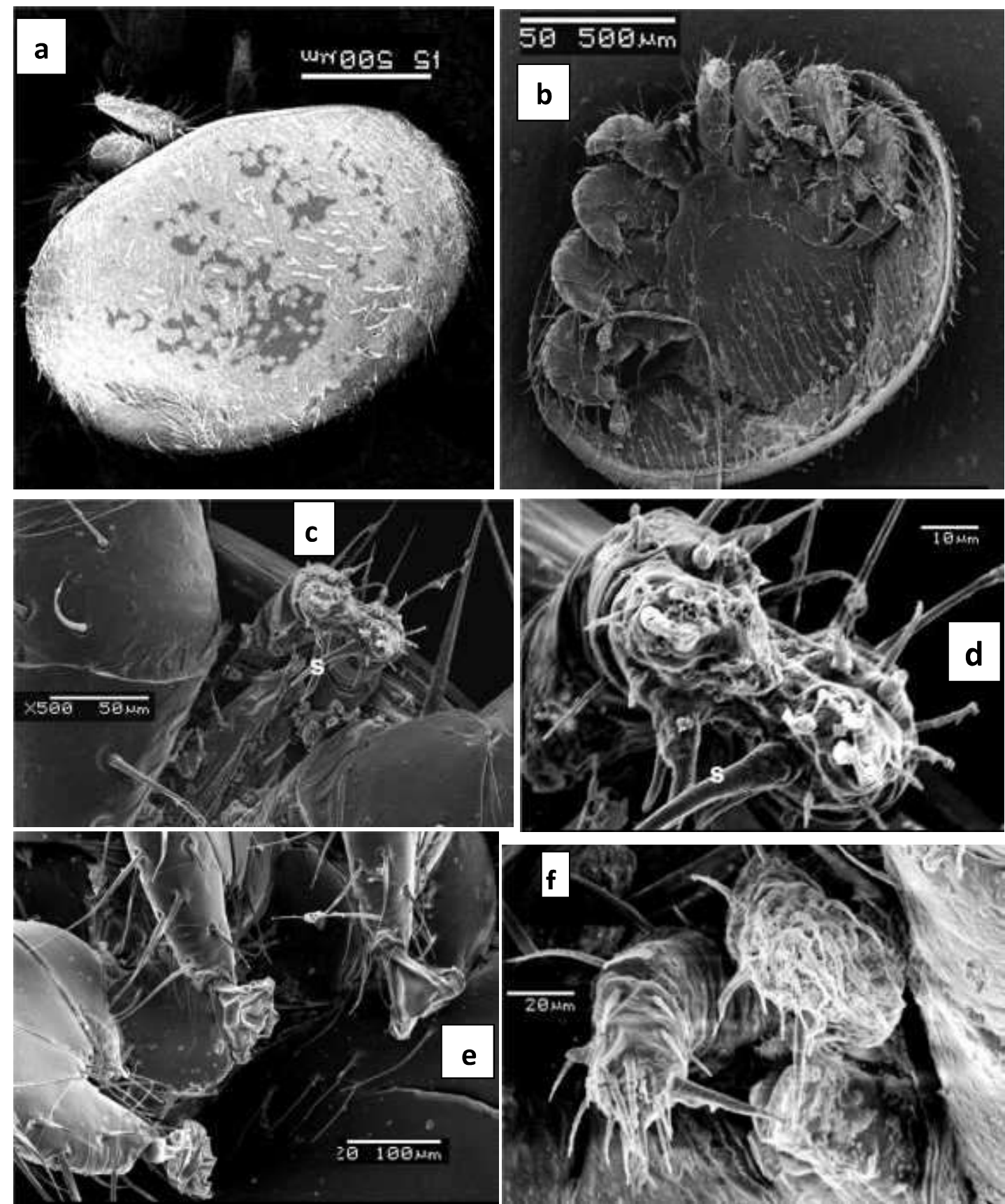

Plate 1:

SEM female $V$. destructor: Fig. a: Dorsal view, gnathosoma protrudes vertically to body axis, magnified dorsal shield showing its' pilose. Fig. b: Ventral view of adult showing sternal, genito-ventral anal plates (shields) with anal plate posteriorly, small setae around anus lying anterior, opisthonotal margin dorsally with 22 pairs of thick hook-like spine. Fig. e: Magnified gnathosoma with two chelicerae, each with 2 small teeth, a pair of stilettos(S). Fig. f: Mouthparts of movable digit of chelicerae lying between pedipalps, tritosternum short chelicerae and hypostome. 

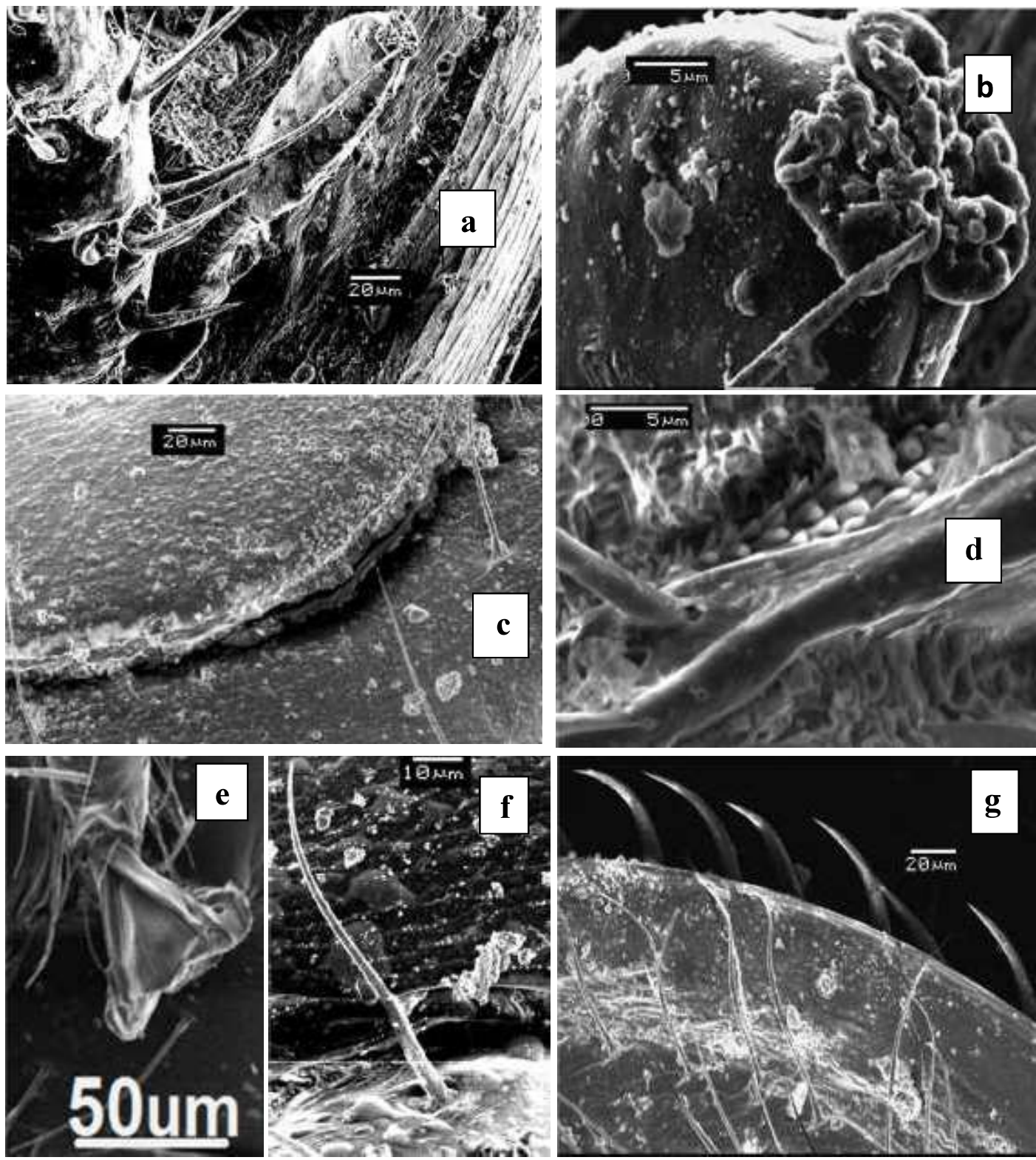

Plate 2:

SEM female $V$. destructor: Fig. a: Lateral view showing dorsal plate, peritreme, stigma (spiracle) and legs located laterally above Coxa III. Fig. b: Magnified peritremated shield end with a slite; peritreme with rose-like lid, curly with a thick inner membrane carrying numerous teeth-like projections. Fig. c: Magnified genitor-ventral shield and genital opening, with scattered small sessile papillae, Fig. d: Posterior end with 5 rows of papillae just post anus. Fig. e: Magnified anterior legs with concave lobed sucker (caruncle). Fig. f: Magnified cox seta with a basal socket. Fig. g: Lateral sides with small, strongly curved spines and different types of setae. 

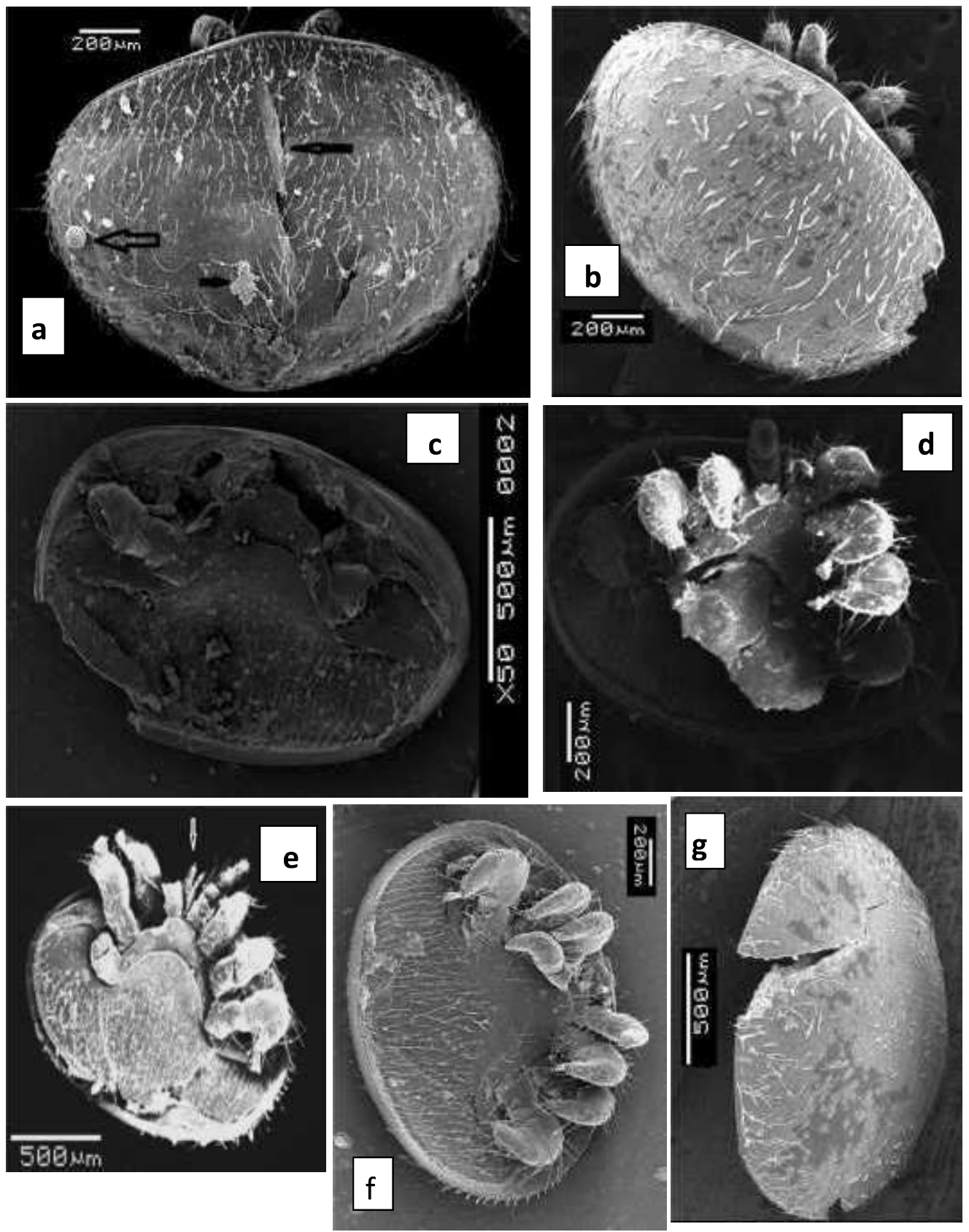

Plate 3:

SEM showing resistance models: Fig. c: Full dump ventrally and legs completely cracked; Fig. f: Mouth parts completely cracked; Figs. a, b \& g: Dorsal side partially cracked; Fig. a: Crackdown dorsally with spores on dorsal shield surface on idiosome seta. Figs. c \& e: Distorted abdomens, missing and stubby, biting legs. 